\title{
Synthesis, Crystal Structures and Catalytic Property of Oxidovanadium(V) Complexes with $N^{\prime}$-(4-Oxopentan-2-ylidene)nicotinohydrazide and 4-Bromo- $N^{\prime}$-(4-oxopentan-2-ylidene) benzohydrazide
}

\author{
Qiwen Yang, ${ }^{1, \star} \mathrm{Pu}$ Wang ${ }^{1}$ and Yan Lei ${ }^{1,2}$ \\ ${ }^{1}$ College of Environment and Ecology, Chongqing University, Chongqing 400030, P. R. China \\ ${ }^{2}$ College of Environmental and Chemistry Engineering, Chongqing Three Gorges University, \\ Chongqing 404000, P. R. China \\ *Corresponding author: E-mail: yangqiwen222@126.com
}

Received: 02-21-2020

\begin{abstract}
A pair of structurally similar oxidovanadium $(\mathrm{V})$ complexes with the general formula [VOLL'], with the hydrazone compounds $N^{\prime}$-(4-oxopentan-2-ylidene)nicotinohydrazide $\left(\mathrm{H}_{2} \mathrm{~L}^{1}\right)$ and 4-bromo- $N^{\prime}$-(4-oxopentan-2-ylidene)benzohydrazide $\left(\mathrm{H}_{2} \mathrm{~L}^{2}\right)$, and the acetohydroxamic acid $(\mathrm{HL})$ as ligands, have been synthesized and structurally characterized by physico-chemical methods and single crystal X-ray determination. Single crystal X-ray analysis indicates that the V atoms in the complexes are in octahedral coordination, with the ONO donor atoms of the hydrazone ligands, and the $\mathrm{OO}$ donor atoms of the acetohydroxamate ligands, as well as an oxido $\mathrm{O}$ atom. The complexes showed good property for the catalytic epoxidation of styrene.
\end{abstract}

Keywords: Oxidovanadium(V) complex; hydrazone ligand; crystal structure; catalytic property

\section{Introduction}

In recent years, due to the environmental and economic issues, green chemistry became the principle for chemical syntheses. One of the major goals in recent research is to find new and efficient catalysts for the industrially important reactions. Hydrazone compounds, the aldehyde- or ketone analogs in which the carbonyl group is replaced by an imine or azomethine group, are considered privileged ligands, because of their simple preparation in an one-pot condensation of aldehydes (or ketones) and primary amines in an alcohol solvent. ${ }^{1}$ The metal complexes of hydrazones have been widely studied for their structures, biological activities and catalytic properties. ${ }^{2}$ Among the complexes, those with $\mathrm{V}$ centers are of particular interest for their biological and catalytic properties. ${ }^{3}$ The epoxidation of alkenes is one of the most widely studied reactions in organic chemistry since epoxides are key starting materials for a wide variety of products. The catalytic epoxidation of olefins by various complexes is a hot research<smiles>CC(=O)C/C(C)=N/NC(=O)c1cccnc1</smiles><smiles>CC(=O)C/C(C)=N/NC(=O)c1ccc(Br)cc1</smiles>

Scheme 1. The hydrazone compounds $\mathrm{H}_{2} \mathrm{~L}^{1}$ and $\mathrm{H}_{2} \mathrm{~L}^{2}$.

topic. ${ }^{4}$ A number of vanadium complexes with Schiff base ligands are reported for the oxidation of various organic substrates. ${ }^{5}$ However, the vanadium complexes with hydrazones derived from hydrazides with acetylacetone have seldom been reported. Herein we report the syntheses, crystal structures and catalytic epoxidation properties of a pair of structurally similar oxidovanadium $(\mathrm{V})$ complexes, [VOL $\left.{ }^{1} \mathrm{~L}^{\prime}\right](\mathbf{1})$ and $\left[\mathrm{VOL}^{2} \mathrm{~L}^{\prime}\right](2)$, where $\mathrm{L}^{1}$ and $\mathrm{L}^{2}$ are the enolate form of $N^{\prime}$-(4-oxopentan-2-ylidene)nicotinohydrazide $\left(\mathrm{H}_{2} \mathrm{~L}^{1}\right)$ and 4-bromo- $N^{\prime}$-(4-oxopentan-2-ylidene)benzohydrazide $\left(\mathrm{H}_{2} \mathrm{~L}^{2}\right)$, respectively (Scheme 1 ), and $\mathrm{L}$ is the anionic form of acetohydroxamic acid (HL'). 


\section{Experimental}

\section{1. Materials}

$\left[\mathrm{VO}(\mathrm{acac})_{2}\right]$, nicotinohydrazide and 4-bromobenzohydrazide were purchased from Aldrich. All other reagents with AR grade were used as received without further purification.

\section{2. Physical Measurements}

Infrared spectra $\left(4000-400 \mathrm{~cm}^{-1}\right)$ were recorded as $\mathrm{KBr}$ discs with a FTS-40 BioRad FT-IR spectrophotometer. The electronic spectra were recorded on a Lambdar 35 spectrometer. Microanalyses $(\mathrm{C}, \mathrm{H}, \mathrm{N})$ of the complex were carried out on a Carlo-Erba 1106 elemental analyzer. Solution electrical conductivity was measured at $298 \mathrm{~K}$ using a DDS-11 conductivity meter. GC analyses were performed on a Shimadzu GC-2010 gas chromatograph.

\section{3. X-ray Crystallography}

Crystallographic data of the complexes were collected on a Bruker SMART CCD area diffractometer with graphite monochromated Mo-K $\alpha$ radiation $(\lambda=0.71073$ $\AA$ ) at 298 (2) K. Absorption corrections were applied by using the multi-scan program. ${ }^{6}$ The structures of the complexes were solved by direct methods and successive Fourier difference syntheses, and anisotropic thermal parameters for all nonhydrogen atoms were refined by full-matrix least-squares procedure against $F^{2}{ }^{7}$ All non-hydrogen atoms were refined anisotropically. The amino $\mathrm{H}$ atoms were located from difference Fourier maps and refined isotropically. The N-H distances were restrained to 0.86(1) $\AA$. The crystallographic data and experimental details for the

Table 1. Crystallographic data for the single crystal of the complexes

\begin{tabular}{lcc}
\hline & $\mathbf{1}$ & $\mathbf{2}$ \\
\hline Empirical formula & $\mathrm{C}_{13} \mathrm{H}_{15} \mathrm{~N}_{4} \mathrm{O}_{5} \mathrm{~V}$ & $\mathrm{C}_{14} \mathrm{H}_{15} \mathrm{BrN}_{3} \mathrm{O}_{5} \mathrm{~V}$ \\
Formula weight & 358.23 & 436.14 \\
Temperature $(\mathrm{K})$ & $298(2)$ & $298(2)$ \\
Crystal system & $\mathrm{Monoclinic}$ & Triclinic \\
Space group & $P 2_{1} / n$ & $P^{-} 1$ \\
$a(\AA)$ & $7.658(1)$ & $7.952(1)$ \\
$b(\AA)$ & $23.873(1)$ & $10.371(1)$ \\
$c(\AA)$ & $8.556(1)$ & $11.613(1)$ \\
$\alpha\left(^{\circ}\right)$ & 90 & $110.733(1)$ \\
$\beta\left(^{\circ}\right)$ & $96.883(1)$ & $96.007(1)$ \\
$\gamma\left({ }^{\circ}\right)$ & 90 & $102.030(1)$ \\
$V\left(\AA^{3}\right)$ & $1552.9(3)$ & $859.2(2)$ \\
$Z$ & 4 & 2 \\
$F(000)$ & 736 & 436 \\
Data/restraints/parameters & $2891 / 1 / 214$ & $3187 / 1 / 222$ \\
Goodness-of-fit on $F^{2}$ & 1.132 & 1.023 \\
$R_{1}, w R_{2}[I>2 \sigma(I)]$ & $0.0491,0.1072$ & $0.0488,0.1047$ \\
$R_{1}, w R_{2}$ (all data) & $0.0618,0.1126$ & $0.0762,0.1189$ \\
\hline
\end{tabular}

structural analysis are summarized in Table 1 , and the selected bond lengths and angles are listed in Table 2.

Table 2. Selected bond distances $(\AA)$ and bond angles $\left({ }^{\circ}\right)$ for the complexes

\begin{tabular}{|c|c|c|}
\hline & 1 & 2 \\
\hline $\mathrm{V} 1-\mathrm{O} 1$ & $1.896(2)$ & $1.886(3)$ \\
\hline $\mathrm{V} 1-\mathrm{O} 2$ & $1.938(2)$ & $1.975(3)$ \\
\hline $\mathrm{V} 1-\mathrm{O} 3$ & $2.228(2)$ & $2.201(3)$ \\
\hline $\mathrm{V} 1-\mathrm{O} 4$ & $1.854(2)$ & $1.869(3)$ \\
\hline $\mathrm{V} 1-\mathrm{O} 5$ & $1.588(2)$ & $1.588(3)$ \\
\hline $\mathrm{V} 1-\mathrm{N} 1$ & $2.059(2)$ & $2.046(3)$ \\
\hline $\mathrm{C} 2-\mathrm{O} 1$ & $1.310(4)$ & $1.315(5)$ \\
\hline $\mathrm{C} 2-\mathrm{C} 3$ & $1.351(4)$ & $1.357(6)$ \\
\hline C4-N1 & $1.314(4)$ & $1.329(5)$ \\
\hline $\mathrm{N} 1-\mathrm{N} 2$ & $1.398(3)$ & $1.393(5)$ \\
\hline C6-N2 & $1.291(4)$ & $1.302(5)$ \\
\hline $\mathrm{C} 6-\mathrm{O} 2$ & $1.303(3)$ & $1.321(5)$ \\
\hline O5-V1-O4 & $96.20(11)$ & $95.96(14)$ \\
\hline O5-V1-O1 & $98.02(12)$ & $98.50(14)$ \\
\hline $\mathrm{O} 4-\mathrm{V} 1-\mathrm{O} 1$ & $104.00(9)$ & $103.84(12)$ \\
\hline $\mathrm{O} 5-\mathrm{V} 1-\mathrm{O} 2$ & $101.39(12)$ & $100.24(13)$ \\
\hline $\mathrm{O} 4-\mathrm{V} 1-\mathrm{O} 2$ & $90.23(9)$ & $100.24(13)$ \\
\hline $\mathrm{O} 1-\mathrm{V} 1-\mathrm{O} 2$ & $154.51(10)$ & $154.79(12)$ \\
\hline O5-V1-N1 & $100.96(11)$ & $101.32(14)$ \\
\hline $\mathrm{O} 4-\mathrm{V} 1-\mathrm{N} 1$ & $159.58(10)$ & $159.63(12)$ \\
\hline O1-V1-N1 & $84.58(9)$ & $84.29(12)$ \\
\hline $\mathrm{O} 2-\mathrm{V} 1-\mathrm{N} 1$ & 75.66(9) & $75.62(12)$ \\
\hline O5-V1-O3 & $171.30(10)$ & $171.74(13)$ \\
\hline O4-V1-O3 & $75.52(8)$ & 75.87(11) \\
\hline $\mathrm{O} 1-\mathrm{V} 1-\mathrm{O} 3$ & $81.69(9)$ & $82.57(12)$ \\
\hline $\mathrm{O} 2-\mathrm{V} 1-\mathrm{O} 3$ & $81.58(9)$ & $81.31(11)$ \\
\hline $\mathrm{N} 1-\mathrm{V} 1-\mathrm{O} 3$ & $87.68(9)$ & $86.92(12)$ \\
\hline
\end{tabular}

\section{4. Synthesis of [VOL1L'] (1)}

Nicotinohydrazide (1.00 mmol, $0.135 \mathrm{~g})$ and [VO $(\mathrm{acac})_{2}$ ] $(1.00 \mathrm{mmol}, 0.265 \mathrm{~g})$ were mixed and stirred in methanol $(50 \mathrm{~mL})$ for $30 \mathrm{~min}$ at $25^{\circ} \mathrm{C}$. Then, acetohydroxamic acid $(1.00 \mathrm{mmol}, 0.0750 \mathrm{~g})$ was added. The final mixture was further stirred for $30 \mathrm{~min}$. The brown solution was evaporated to remove three quarters of the solvents under reduced pressure, yielding deep brown solid of the complex. Yield: $0.26 \mathrm{~g}$ (72\%). Well-shaped single crystals suitable for X-ray diffraction were obtained by recrystallization of the solid from methanol. Elemental analysis found: $\mathrm{C}, 43.75 ; \mathrm{H}, 4.31 ; \mathrm{N}, 15.56 \% . \mathrm{C}_{13} \mathrm{H}_{15} \mathrm{~N}_{4} \mathrm{O}_{5} \mathrm{~V}$ calcd: C, 43.59; H, 4.22; N, 15.64\%. IR data $\left(\mathrm{KBr}, \mathrm{cm}^{-1}\right): 3287$, $3119,2917,2850,1628,1556,1490,1400,1332,1280,1168$, $1116,1033,961,806,712,585$. UV-Vis data in methanol $\left[\lambda_{\max }(\mathrm{nm}), \varepsilon\left(\mathrm{L} \mathrm{mol}^{-1} \mathrm{~cm}^{-1}\right)\right]: 235,1.62 \times 10^{4} ; 273,1.58 \times$ $10^{4} ; 345,9.67 \times 10^{3} ; 460,7.72 \times 10^{3}$.

\section{5. Synthesis of [VOL $\left.{ }^{2} L^{\prime}\right](2)$}

4-Bromobenzohydrazide $(1.00 \mathrm{mmol}, 0.214 \mathrm{~g})$ and [VO(acac $\left.)_{2}\right](1.00 \mathrm{mmol}, 0.265 \mathrm{~g})$ were mixed and stirred 
in methanol $(50 \mathrm{~mL})$ for $30 \mathrm{~min}$ at $25^{\circ} \mathrm{C}$. Then, acetohydroxamic acid $(1.00 \mathrm{mmol}, 0.0750 \mathrm{~g})$ was added. The final mixture was further stirred for $30 \mathrm{~min}$. The brown solution was evaporated to remove three quarters of the solvents under reduced pressure, yielding deep brown solid of the complex. Yield: $0.34 \mathrm{~g}$ (77\%). Well-shaped single crystals suitable for X-ray diffraction were obtained by recrystallization of the solid from methanol. Elemental analysis found: $\mathrm{C}, 38.37 ; \mathrm{H}, 3.53 ; \mathrm{N}, 9.72 \% . \mathrm{C}_{14} \mathrm{H}_{15} \mathrm{BrN}_{3} \mathrm{O}_{5} \mathrm{~V}$ calcd: $\mathrm{C}, 38.55 ; \mathrm{H}, 3.47 ; \mathrm{N}, 9.63 \%$. IR data $\left(\mathrm{KBr}, \mathrm{cm}^{-1}\right): 3272$, 3105, 2913, 2880, 1636, 1422, 1145, 1085, 958, 846, 532. UV-Vis data in methanol $\left[\lambda_{\max }(\mathrm{nm}), \varepsilon\left(\mathrm{L} \mathrm{mol}^{-1} \mathrm{~cm}^{-1}\right)\right]$ : $275,1.73 \times 10^{4} ; 343,1.05 \times 10^{4} ; 435,5.62 \times 10^{3}$.

\section{6. Styrene Epoxidation}

The epoxidation reaction was carried out at room temperature in acetonitrile under $\mathrm{N}_{2}$ atmosphere with constant stirring. The composition of the reaction mixture was $2.00 \mathrm{mmol}$ of styrene, $2.00 \mathrm{mmol}$ of chlorobenzene (internal standard), $0.10 \mathrm{mmol}$ of the complexes (catalyst) and $2.00 \mathrm{mmol}$ iodosylbenzene or sodium hypochlorite (oxidant) in $5.00 \mathrm{~mL}$ freshly distilled acetonitrile. When the oxidant was sodium hypochlorite, the solution was buffered to $\mathrm{pH} 11.2$ with $\mathrm{NaH}_{2} \mathrm{PO}_{4}$ and $\mathrm{NaOH}$. The composition of reaction medium was determined by GC with styrene and styrene epoxide quantified by the internal standard method (chlorobenzene). All other products detected by GC were mentioned as others. For each complex the reaction time for maximum epoxide yield was determined by withdrawing periodically $0.1 \mathrm{~mL}$ aliquots from the reaction mixture and this time was used to monitor the efficiency of the catalyst on performing at least two independent experiments. Blank experiments with each oxidant and using the same experimental conditions except catalyst were also performed.

\section{Results and Discussion}

\section{1. Chemistry}

Complexes $\mathbf{1}$ and $\mathbf{2}$ were readily prepared by reaction of $\mathrm{VO}(\mathrm{acac})_{2}$, acetohydroxamic acid with nicotinohydrazide and 4-bromobenzohydrazide, respectively, in methanol (Scheme 2). The hydrazone ligands were formed by the condensation reactions of the hydrazides with the acetylacetone ligand of $\mathrm{VO}(\mathrm{acac})_{2}$. The reaction progresses are accompanied by an immediate color change of the solution from colorless to brown. The molar conductivities $\left(\Lambda_{\mathrm{M}}=37 \Omega^{-1} \mathrm{~cm}^{2} \mathrm{~mol}^{-1}\right.$ for $\mathbf{1}$ and $43 \Omega^{-1} \mathrm{~cm}^{2} \mathrm{~mol}^{-1}$ for 2$)$ measured in methanol are consistent with the values expected for non-electrolyte. ${ }^{8}$ The structure of complex $\mathbf{2}$ has been reported but with different crystal system and space group (orthorhombic Pbca). ${ }^{8}$

\section{2. Crystal Structure Description of the Complexes}

Single-crystal X-ray analysis shows that both complexes are structurally similar mononuclear oxidovanadi$\mathrm{um}(\mathrm{V})$ compounds. The differences between the two complexes are the terminal groups, viz. pyridinyl for $\mathbf{1}$ and bromophenyl for $\mathbf{2}$. The ORTEP plots of the complexes 1 and $\mathbf{2}$ are shown in Figs. 1 and 2, respectively. The V atom is in distorted octahedral geometry, which is coordinated by the $\mathrm{NO}_{2}$ donor atoms of the hydrazone ligand and the hydroxyl $\mathrm{O}$ atom of the acetylhydroxamate ligand in the equatorial plane, and by the carbonyl $\mathrm{O}$ atom of the acetylhydroxamate ligand and the oxido $\mathrm{O}$ atom at the two axial positions. The metal atoms are displaced toward the axial oxido O atoms (O5) by $0.29-0.30 \AA$ from the equatorial planes of both complexes. The distortion of the octahedral coordination of the complexes can be observed from the bond angles (Table 2) related to the V atoms. The cis- and

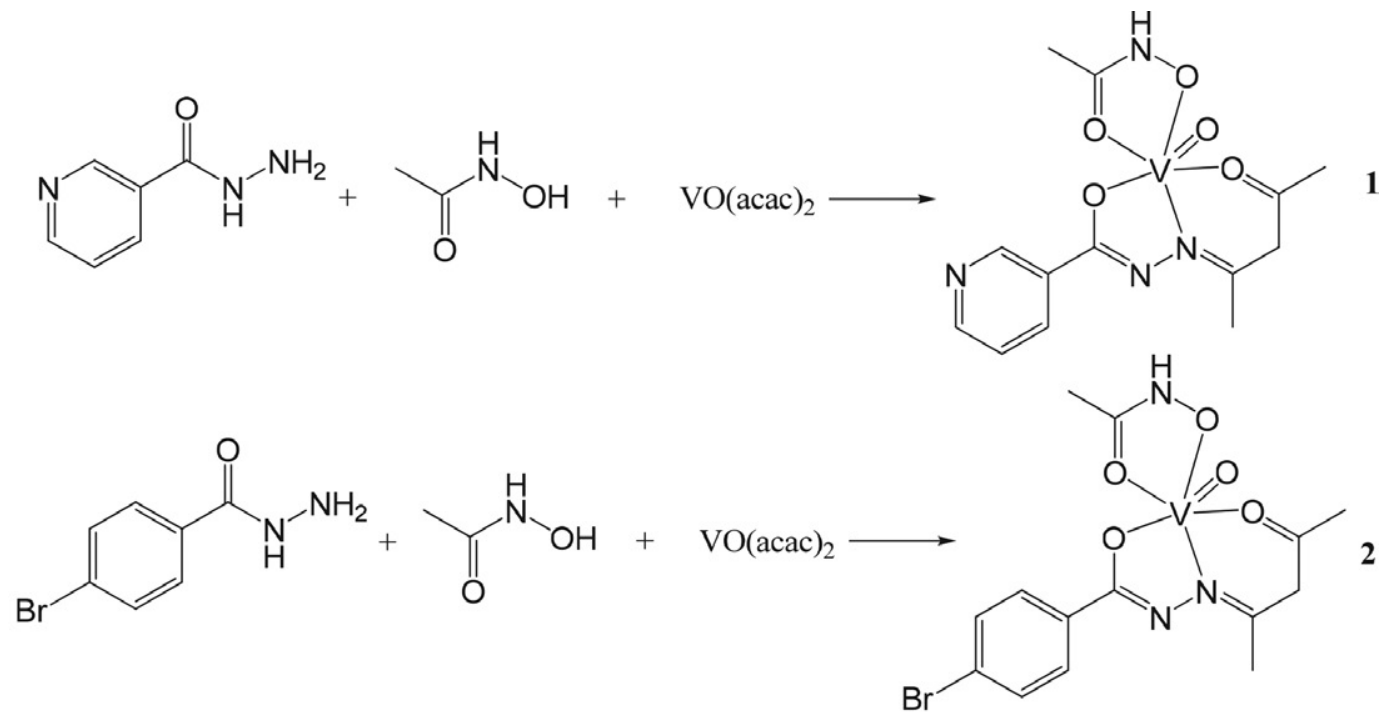

Scheme 2. The preparation of the complexes. 
Table 3. Hydrogen bond distances $(\AA)$ and bond angles $\left(^{\circ}\right)$ for the complexes

\begin{tabular}{|c|c|c|c|c|}
\hline$D-\mathrm{H} \cdots A$ & $d(D-H)$ & $d(\mathrm{H} \cdots A)$ & $d(D \cdots A)$ & Angle $(D-\mathbf{H} \cdots A)$ \\
\hline \multicolumn{5}{|l|}{$\mathbf{1}$} \\
\hline $\mathrm{N} 3-\mathrm{H} 3 \mathrm{~A} \cdots \mathrm{N} 4^{\# 1}$ & $0.86(1)$ & $1.96(1)$ & $2.813(4)$ & $171(4)$ \\
\hline $\mathrm{C} 8-\mathrm{H} 8 \cdots \mathrm{O} 4^{\# 2}$ & 0.93 & 2.55 & $3.053(3)$ & $114(5)$ \\
\hline \multicolumn{5}{|l|}{2} \\
\hline $\mathrm{N} 3-\mathrm{H} 3 \mathrm{~A} \cdots \mathrm{O} 2^{\# 3}$ & $0.86(1)$ & $1.99(1)$ & $2.838(4)$ & $170(5)$ \\
\hline $\mathrm{C} 1-\mathrm{H} 1 \mathrm{~A} \cdots \mathrm{O} 1^{\# 4}$ & 0.96 & 2.58 & $3.492(5)$ & $159(6)$ \\
\hline $\mathrm{C} 12-\mathrm{H} 12 \cdots \mathrm{O} 3^{\# 5}$ & 0.93 & 2.57 & $3.253(5)$ & $131(6)$ \\
\hline
\end{tabular}

trans- angles related to the $\mathrm{V}$ atoms at the equatorial planes are in the range of $75.52(8)-104.00(9)^{\circ}$ and $154.51(10)-$ $171.30(10)^{\circ}$ for 1 and $75.62(12)-103.84(12)^{\circ}$ and $154.79(12)-171.74(13)^{\circ}$ for 2 . The deviations from the ideal octahedral geometry are mainly origin from the strain created by the five-membered chelate rings $\mathrm{N} 1-\mathrm{V} 1-\mathrm{O} 2$ and $\mathrm{O} 3-\mathrm{V} 1-\mathrm{O} 4$. The bond lengths of $\mathrm{V}-\mathrm{O}$ and $\mathrm{V}-\mathrm{N}$ (Table 2) of both complexes are similar to each other, and comparable to those in other $\mathrm{V}$ complexes in literature. ${ }^{9,10}$ The terminal V1-O5 [1.588(2) $\AA$ ] bond distances of both complexes agree well with the corresponding values reported for related systems. ${ }^{11}$ Because of the trans influence of the oxido groups, the distances to the O3 atoms (2.20-2.23 $\AA$ ) are considerably elongated, making the $\mathrm{O} 3$ atoms weakly coordinated to the $\mathrm{V}$ atoms. Such elongation has previously been observed in other complexes with similar structures. ${ }^{12}$ The hydrazone ligands coordinate to the $\mathrm{V}$ atoms through dianionic form, which can be seen from the bond lengths of C6-O2, N1-N2, C2-C3 and C2-O1. The bonds C6-O2 and $\mathrm{C} 2-\mathrm{O} 1$ are obviously longer than typical double bonds, and the bonds C6-N2 and C2-C3 are obviously shorter than typical single bonds. This phenomenon is not uncommon for hydrazone complexes. ${ }^{13}$

In the crystal structures of complex $\mathbf{1}$, the molecules are linked through $\mathrm{N}-\mathrm{H} \cdot \cdots \mathrm{N}$ hydrogen bonds between the amino group of the acetohydroxamate ligand and the pyridine $\mathrm{N}$ atom, as well as the $\mathrm{C}-\mathrm{H} \cdots \mathrm{O}$ hydrogen bonds be-

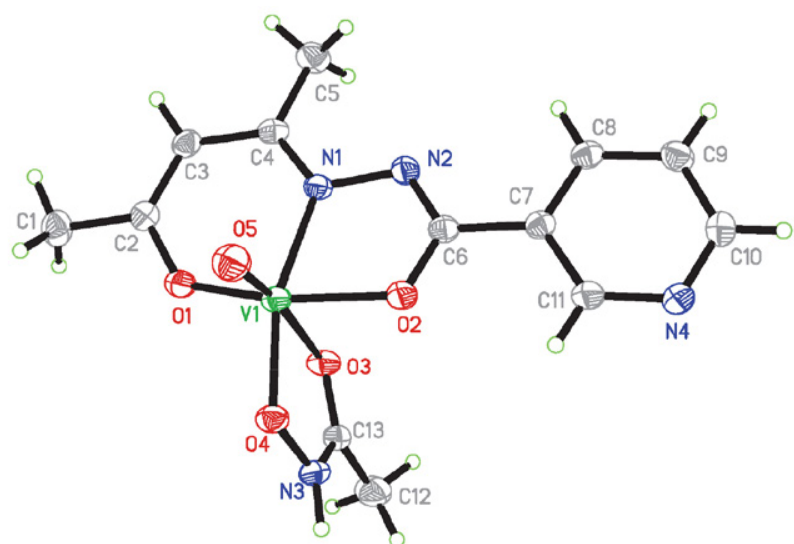

Fig. 1. ORTEP diagram of complex 1 with $30 \%$ thermal ellipsoid. tween the pyridine $\mathrm{C}-\mathrm{H}$ group and the hydroxyl $\mathrm{O}$ atom of the acetohydroxamate ligand (Table 3), to form one dimensional zigzag chains running along the $a$ axis (Fig. 3). In the crystal structures of complex 2 , the molecules are

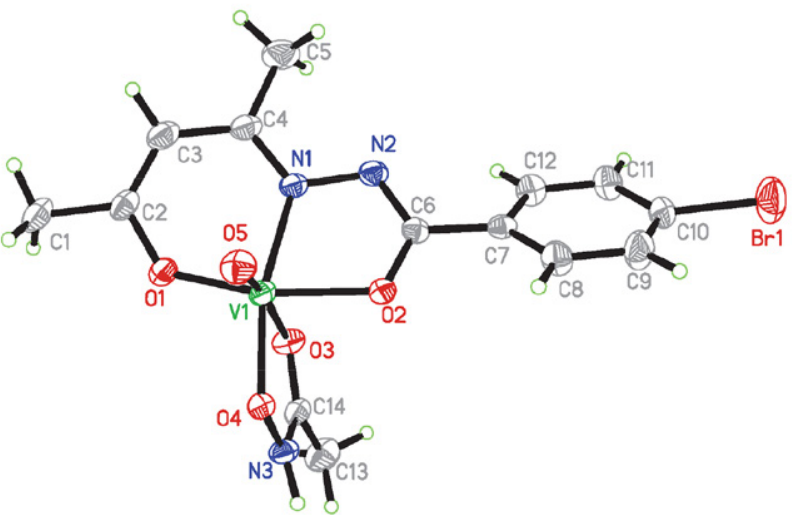

Fig. 2. ORTEP diagram of complex 2 with $30 \%$ thermal ellipsoid.

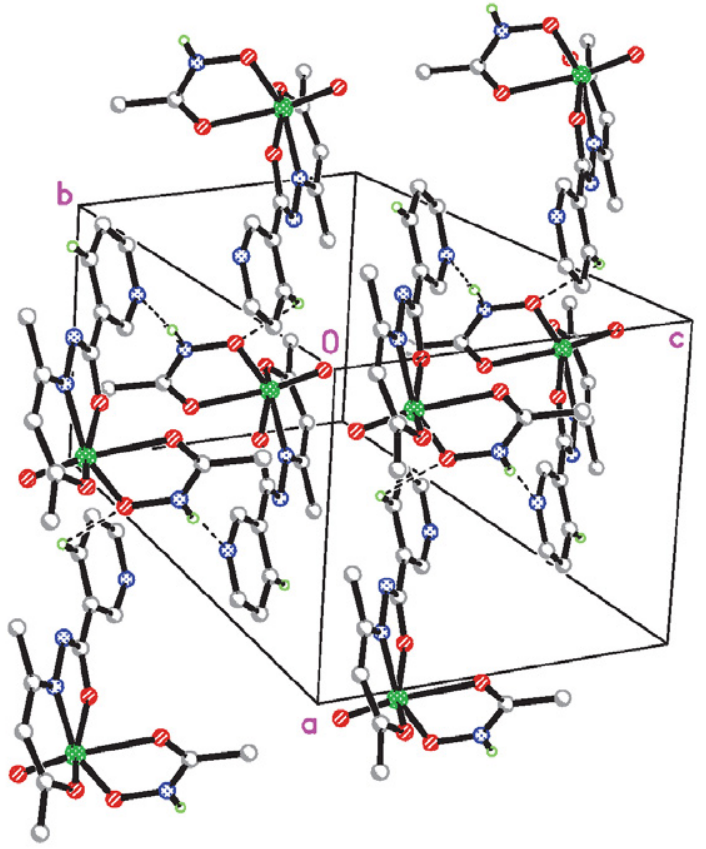

Fig. 3. Molecular packing structure of complex 1 linked by hydrogen bonds. 


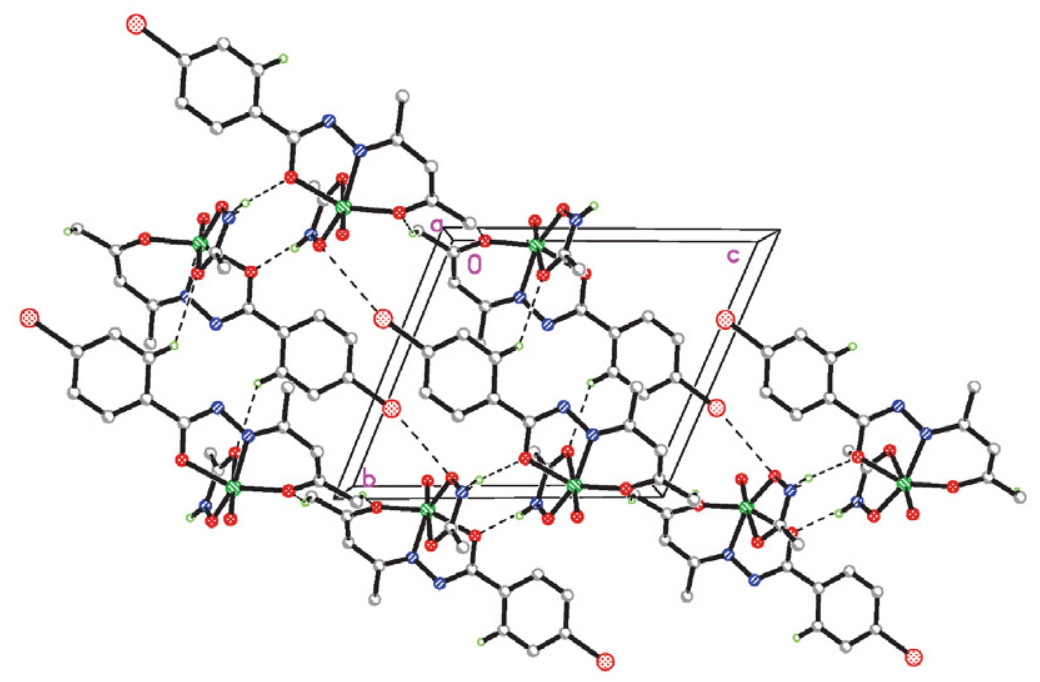

Fig. 4. Molecular packing structure of complex 2 linked by hydrogen bonds.

linked through $\mathrm{N}-\mathrm{H}$...O hydrogen bonds between the amino group of the acetohydroxamate ligand and the carbonyl $\mathrm{O}$ atom of the hydrazone ligand, as well as the $\mathrm{C}-\mathrm{H} \cdots \mathrm{O}$ hydrogen bonds between the benzene $\mathrm{C}-\mathrm{H}$ group and the carbonyl $\mathrm{O}$ atom of the acetohydroxamate ligand (Table 3), to generate layers parallel to the $b c$ direction (Fig. 4).

\section{3. Infrared and Electronic Spectra}

The sharp absorptions at about $3280 \mathrm{~cm}^{-1}$ for the spectra of both complexes are attributed to the $\mathrm{N}-\mathrm{H}$ bonds of the amino groups. The bands in the region 3120-2850 $\mathrm{cm}^{-1}$ are assigned to the $\mathrm{C}-\mathrm{H}$ bonds. The intense bands at about $1630 \mathrm{~cm}^{-1}$ are assigned to the vibration of the $\mathrm{C}=\mathrm{N}$ group. ${ }^{1,12 \mathrm{~b}}$ The characteristic of the spectra of both complexes is the exhibition of sharp bands at about $960 \mathrm{~cm}^{-1}$, corresponding to the $\mathrm{V}=\mathrm{O}$ stretching vibration. ${ }^{1,13 \mathrm{~b}}$ The appearance of a single band in this region indicates the existence of monomeric six-coordinated $\mathrm{V}=\mathrm{O}$ units instead of the polymeric units. ${ }^{14}$ This is approved by the single crystal structure determination.

In the UV-Vis spectra of the complexes, the bands at about $345 \mathrm{~nm}$ and $275 \mathrm{~nm}$ are attributed to the $\pi-\pi^{*}$ and $n-\pi^{*}$ transitions. ${ }^{13 \mathrm{~b}, 15}$ The weak bands at $430-470 \mathrm{~nm}$ are attributed to intramolecular charge transfer transitions from the $p_{\pi}$ orbital on the nitrogen and oxygen to the empty $d$ orbitals of the $\mathrm{V}$ atoms. ${ }^{12 \mathrm{~b}, 13 \mathrm{~b}}$

\section{4. Catalytic Property}

The percentage of conversion of styrene, selectivity for styrene oxide, yield of styrene oxide and reaction time to obtain maximum yield using both the oxidants are shown in Fig. 5. The data reveals that the complexes as catalysts convert styrene most efficiently in the presence of both oxidants. Nevertheless, the catalysts are selective (over 90\%) towards the formation of styrene epoxides de- spite of the formation of by-products like benzaldehyde, phenylacetaldehyde, styrene epoxides derivative, alcohols etc. From the data it is also clear that the complexes exhibit high efficiency for styrene epoxide yields. When the reactions were carried out with $\mathrm{PhIO}$ at $2 \mathrm{~h}$, styrene conversions of complexes $\mathbf{1}$ and $\mathbf{2}$ are $95 \%$ and $87 \%$, respectively. When the reactions were carried out with $\mathrm{NaOCl}$ at $3 \mathrm{~h}$, styrene conversions of complexes $\mathbf{1}$ and $\mathbf{2}$ are $93 \%$ and $84 \%$, respectively. It is evident that between $\mathrm{PhIO}$ and $\mathrm{Na}-$ $\mathrm{OCl}$, the former acts as a better oxidant with respect to both styrene conversion and styrene epoxide selectivity. Moreover, complex $\mathbf{2}$ has better conversion values than complex 1, which is in accordance with that the presence of electronegative groups in the ligands increases the catalytic efficiency of the complexes. ${ }^{16}$ The epoxide yields for the complexes 1 and 2 using $\mathrm{PhIO}$ and $\mathrm{NaOCl}$ as oxidants are about $80 \%$ and $75 \%$, respectively. Thus, both complexes have good and similar catalytic properties on the oxidation of styrene.

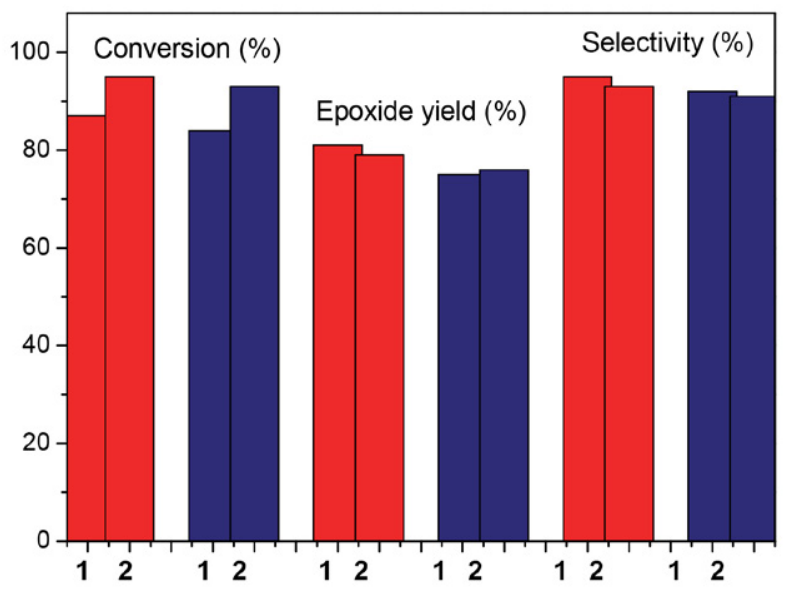

Fig. 5. Catalytic epoxidation results. The red and blue columns represent the results catalyzed by $\mathrm{PhIO}(2 \mathrm{~h})$ and $\mathrm{NaOCl}(3 \mathrm{~h})$, respectively. 


\section{Conclusion}

In summary, two oxidovanadium $(\mathrm{V})$ complexes derived from hydrazone and acetylhydroxamate ligands were prepared and characterized. The $\mathrm{V}$ atoms in the complexes are in octahedral coordination. Both complexes have good catalytic property for the epoxidation of styrene with the good selectivity (over 90\%) and high styrene epoxide and epoxide yields. The presence of electronegative groups in the ligands can increase the catalytic efficiency of the complexes.

\section{Supplementary Material}

CCDC 1985429 (1) and 1985432 (2) contain the supplementary crystallographic data for this paper. These data can be obtained free of charge via http://www.ccdc.cam. ac.uk/conts/retrieving.html, or from the Cambridge Crystallographic Data Centre, 12 Union Road, Cambridge CB2 1EZ, UK; fax: (+44) 1223-336-033; or e-mail: deposit@ ccdc.cam.ac.uk.

\section{Acknowledgements}

This project was supported by the Scientific and Technological Research Program of Chongqing Municipal Education Commission (Grant No. KJQN201801222), the Chunhui Project from Education Ministry of China (Grant No. Z2015140), the Key Laboratory of Water Environment Evolution and Pollution Control in Three Gorges Reservoir (Chongqing Three Georges University) (Grant No. 0969809) and the Key Cultivation Project of Chongqing Three Gorges University (Grant No. 17ZD12).

\section{References}

1. Grivani, G. Bruno, H. A. Rudbari, A. D. Khalaji, P. Pourteimouri, Inorg. Chem. Commun. 2012, 18, 15-20.

DOI:10.1016/j.inoche.2011.12.044

2. (a) S. Dasgupta, S. Karim, S. Banerjee, M. Saha, K. Das Saha, D. Das, Dalton Trans. 2020, 49, 1232-1240;

DOI:10.1039/C9DT04636D

(b) M. Cuccioloni, L. Bonfili, V. Cecarini, M. Nabissi, R. Pettinari, F. Marchetti, R. Petrelli, L. Cappellacci, M. Angeletti, A. M. Eleuteri, ChemMedChem 2020, 15, 105-113; DOI:10.1002/cmdc.201900551

(c) A. A. Khandar, Z. M. Azar, M. Eskandani, C. B. Hubschle, S. van Smaalen, B. Shaabani, Y. Omidi, Polyhedron 2019, 171, 237-248; DOI:10.1016/j.poly.2019.06.026

(d) M. Sutradhar, M. V. Kirillova, M. F. C. G. da Silva, C. M. Liu, A. J. L. Pombeiro, Dalton Trans. 2013, 42, 16578-16587; DOI:10.1039/c3dt52453a

(e) D. Sadhukhan, A. Ray, G. Pilet, C. Rizzoli, G. M. Rosair, C. J. Gomez-Garcia, S. Signorella, S. Bellu, S. Mitra, Inorg. Chem. 2011, 50, 8326-8339; DOI:10.1021/ic200846j (f) O. Pouralimardan, A. C. Chamayou, C. Janiak, H. Hosseini-Monfared, Inorg. Chim. Acta 2007, 360, 1599-1608. DOI:10.1016/j.ica.2006.08.056

3. (a) H. H. Monfared, S. Kheirabadi, N. A. Lalami, P. Mayer, Polyhedron 2011, 30, 1375-1384; DOI:10.1016/j.poly.2011.02.005 (b) H. Hosseini-Monfared, R. Bikas, P. Mahboubi-Anarjan, A. J. Blake, V. Lippolis, N. B. Arslan, C. Kazak, Polyhedron 2014, 69, 90-102; DOI:10.1016/j.poly.2013.11.020

(c) H. Y. Qian, Inorg. Nano-Met. Chem. 2018, 48, 461-466; DOI:10.1080/24701556.2019.1569689

(d) H. Y. Qian, Russ. J. Coord. Chem. 2017, 43, 780-786; DOI:10.1134/S1070328417110070

(e) H.-Y. Qian, Acta Chim. Slov. 2019, 66, 995-1001; DOI:10.4149/neo_2019_190112N36

(f) E.-C. Liu, W. Li, X.-S. Cheng, Acta Chim. Slov. 2019, 66, 971-977;

(g) C.-L. Zhang, X.-Y. Qiu, S.-J. Liu, Acta Chim. Slov. 2019, 66, 719-725; DOI:10.17344/acsi.2019.5241

(h) L.-W. Xue, Y.-J. Han, X.-Q. Luo, Acta Chim. Slov. 2019, 66, 622-628. DOI:10.17344/acsi.2019.5039

4. (a) K. Moghe, A. K. Sutar, I. K. Kang, K. C. Gupta, RSC Advances 2019, 9, 30823-30834; DOI:10.1039/C9RA05811G

(b) B. Rezazadeh, A. R. Pourali, A. Banaei, H. Behniafar, J. Coord. Chem. 2019, 72, 3401-3416.

DOI:10.1080/00958972.2019.1691724

5. (a) M. S. S. Adam, O. M. El-Hady, F. Ullah, RSC Advances 2019, 9, 34311-34329; DOI:10.1039/C9RA06816C

(b) A. Najafian, T. R. Cundari, Inorg. Chem. 2019, 58, $12254-$ 12263; DOI:10.1021/acs.inorgchem.9b01696

(c) N. C. Jana, M. Patra, P. Brandao, A. Panja, Polyhedron 2019, 164, 23-34. DOI:10.1016/j.poly.2019.02.024

6. L. Krause, R. Herbst-Irmer, G. M. Sheldrick, D. Stalke, J. Appl. Crystallogr. 2015, 48, 3-10.

DOI:10.1107/S1600576714022985

7. (a) G. M. Sheldrick, Acta Crystallogr. 2015, A71, 3-8; DOI:10.1107/S2053273314026370

(b) G. M. Sheldrick, Acta Crystallogr. 2015, C71, 3-8.

8. W. J. Geary, Coord. Chem. Rev. 1971, 7, 81-122.

DOI:10.1016/S0010-8545(00)80009-0

9. X. Y. Qiu, S. J. Liu, J. X. Lei, Y. T. Ye, Russ. J. Coord. Chem. 2017, 43, 396-403. DOI:10.1134/S1070328417060069

10. (a) N. Lotfi, I. Sheikhshoaei, S. Y. Ebrahimipour, H. Krautscheid, J. Mol. Struct. 2017, 1149, 432-438;

DOI:10.1016/j.molstruc.2017.08.010

(b) S. K. Mal, M. Mitra, H. R. Yadav, C. S. Purohit, A. R. Choudhury, R. Ghosh, Polyhedron 2016, 111, 118-122.

DOI:10.1016/j.poly.2016.03.033

11. (a) S. Guo, N. Sun, Y. Ding, A. Li, Y. Jiang, W. Zhai, Z. Li, D. Qu, Z. You, Z. Anorg. Allg. Chem. 2018, 644, 1172-1176; DOI:10.1002/zaac.201800060

(b) L. Li, K.-W. Lv, Y.-T. Li, G.-F. Jiang, Y. Xin, L. Ye, Y. Zhang, H. Liu, C.-N. Shang, Z.-L. You, Chinese J. Inorg. Chem. 2017, 33, 905-912;

(c) Z. You, B. Zheng, T. Yang, F. Liu, X.-S. Cheng, J. Coord. Chem. 2016, 69, 1371-1379.

DOI:10.1080/00958972.2016.1171856 
12. (a) M. R. Maurya, S. Agarwal, C. Bader, M. Ebel, D. Rehder, Dalton Trans. 2005, 537-544;

(b) H. H. Monfared, S. Alavi, R. Bikas, M. Vahedpour, P. Mayer, Polyhedron 2010, 29, 3355-3362.

DOI:10.1016/j.poly.2010.09.029

13. (a) Y. M. Li, L. Y. Xu, M. M. Duan, J. H. Wu, Y. H. Wang, K. X. Dong, M. X. Han, Z. L. You, Inorg. Chem. Commun. 2019, 105, 212-216; DOI:10.1016/j.inoche.2019.05.011

(b) L. Y. Xu, Y. M. Li, M. M. Duan, Y. X. Li, M. X. Han, J. H. Wu, Y. H. Wang, K. X. Dong, Z. L. You, Polyhedron 2019, 165, 138-142. DOI:10.1016/j.poly.2019.03.016

14. (a) R. Ando, S. Mori, M. Hayashi, T. Yagyu, M. Maeda, Inorg. Chim. Acta 2004, 357, 1177-1184;

DOI:10.1016/j.ica.2003.09.033 (b) C. J. Chang, J. A. Labinger, H. B. Gray, Inorg. Chem. 1997, 36, 5927-5930; DOI:10.1021/ic970824q

(c) R. Ando, H. Ono, T. Yagyu, M. Maeda, Inorg. Chim. Acta 2004, 357, 2237-2244. DOI:10.1016/j.ica.2003.12.031

15. S. Mondal, M. Mukherjee, K. Dhara, S. Ghosh, J. Ratha, P. Banerjee, A. K. Mukherjee, Cryst. Growth Des. 2007, 7, 17161721. DOI:10.1021/cg060753i

16. (a) J. Rahchamani, M. Behzad, A. Bezaatpour, V. Jahed, G. Dutkiewicz, M. Kubicki, M. Salehi, Polyhedron 2011, 30, 2611-2618; DOI:10.1016/j.poly.2011.07.011

(b) D. M. Boghaei, A. Bezaatpour, M. Behzad, J. Mol. Catal. A: Chem. 2006, 245, 12-16.

DOI:10.1016/j.molcata.2005.09.022

\section{Povzetek}

Sintetizirali smo dva strukturno sorodna oksidovanadijeva(V) kompleksa s splošno formulo [VOLL'], s hidrazonoma $N^{\prime}$-(4-oksopentan-2-iliden)nikotinohidrazid $\left(\mathrm{H}_{2} \mathrm{~L}^{1}\right)$ in 4-bromo- $N^{\prime}$-(4-oksopentan-2-iliden)benzohidrazid $\left(\mathrm{H}_{2} \mathrm{~L}^{2}\right)$ in $\mathrm{z}$ acetohidroksamsko kislino (HL') kot ligandi ter ju okarakterizirali z fiziko-kemijskimi metodami in monokristalno rentgensko difrakcijo. Kristalna analiza razkriva, da je V atom v oktaedričnem okolju z ONO donorskimi atomi hidrazonskega liganda, z OO donorskima atomoma acetohidroksamatnega liganda ter oksido O atomom. Kompleksa izkazujeta dobre lastnosti pri katalitični epoksidaciji stirena.

Except when otherwise noted, articles in this journal are published under the terms and conditions of the Creative Commons Attribution 4.0 International License 